\title{
THE WRATH OF YHWH
}

\section{By s. ERLANDSSON}

The frequency of the expression 'the wrath of YHWH' in the Old Testament is striking. The different nouns for wrath occur about 375 times with reference to the wrath of God and about 80 times referring to the wrath of man. This circumstance has caused problems when dealing with the concept of God in the Old Testament. How are we to understand the relationship between God's wrath and God's love? This question has been especially embarrassing for those who regard the Old Testament texts as holy and decisive for their own concept of God. The most radical method is, of course, to make a complete discharge of the wrath from the concept of God, as for example Schleiermacher did. Others have regarded the wrath-motif as a reminiscense from an earlier and more primitive stage in the history of religion in order to justify a separation of the wrathmotif from God's real nature of love. It is clear that often an apologetic interest determines the attitude to the wrath of God in the Old Testament. But a scientific approach demands that we try to understand the statements in their own context.

Even if we try to interpret the Old Testament as it now stands, it is nevertheless difficult to get rid of the impression that the wrath of God must be something negative and strange to a perfect being. When meeting statements about the goodness and the wrath of God in the same context (e.g. Na. I:6, 7; Is. $61: 2$ and 63:4) it is hard to make them harmonize. This tension has often been taken to show that in YHWH opposite elements are reflected just as in the oriental despot. Now and then something demonic and capricious appears in YHWH which is not co-ordinated with His love. Lindblom, for example, holds that it is 'für alttestamentliche Gottesanschauung typisch, dass Liebe und Zorn im Wesen Gottes gerade wie in einem orientalischen Herrscher nebeneinander liegen, ohne irgenwie 
ausgeglichen zu werden'. ${ }^{1}$ But we cannot take it for granted that what look to us like disparate elements in the nature of God were also understood in the same way by the author of the text. How can we know that when a text combines love and wrath in YHWH the author means that love and wrath in YHWH have the same relationship to each other as in an oriental despot?

The basis for a negative evaluation of the wrath of God as something incompatible with a good and perfect nature seems to be the experience of human wrath as something which is usually negative and worthy of blame. Human wrath which reflects the protection of one's personal rights is characterized as sin also in the Old Testament, and especially in the Wisdom literature it is pointed out again and again that wrath is dangerous because it brings misfortune and evil (Pr. 6:34; $15: 1 ; 16: 14 ; 19: 19 ; 27: 4)$. From this consideration it is easy to draw the conclusion that the divine wrath is also something imperfect, particularly since the wrath-terminology for God and man is partly identical. It is true that the words חָר ๆX, wrath, but all the same the wrath of YHWH has something in common with human wrath.

It is obvious, however, that the texts themselves never depict the divine wrath as something illegitimate and unfair. Even if the action of YHWH on some occasions seems to the reader to be without reason (e.g. Ex. 4:24ff.), the author himself does not usually hesitate about his description but seems to mean that YHWH's reaction is reasonable and in line with His holiness and righteousness. If we also pay attention to the actual context, it is assumed that the wrath of God is caused by some violation of God's holiness or commandments almost without any exceptions.

The anthropopathisms do not necessarily imply that God has limits and weakness just as a human being. For the prophets clearly point out that God is God and not a man. He is spirit and not flesh, $\mathrm{He}$ is holy, i.e. of a totally different character from man. YHWH has to be described in human language, and in the picture of a God who is represented as a living person

$1 \mathrm{~J}$. Lindblom, 'Zur Frage der Eigenart der alttestamentlichen Religion', BZAW 66 (1936), 135 . 
anthropomorphisms and anthropopathisms are necessary elements.

We shall now try to point out briefly some traits in the nature of divine wrath according to the Old Testament. The wrath of YHWH is first of all connected with the concept of the covenant. YHWH is the name of the God of the covenant, and the combination of an expression for wrath with a word for God almost always had the divine name of YHWH. More than fifty times the words ๆ with YHWH, out of these the expression יהוה ס forty times. The expression typically enough in Psalm 78:31 and in Numbers 22:22.

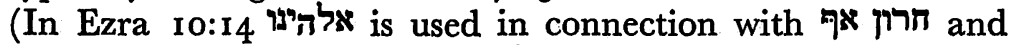

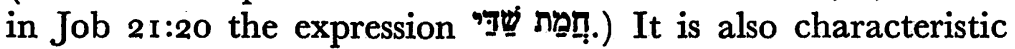
that Genesis lacks terms for the wrath of God. In the covenant the covenantal conditions are revealed and when the people or individuals among the people do not follow them, the wrath of God will be kindled. The blessing and the curse are dependent on man's relation to the God of the covenant. The apostasy of the people from YHWH inflames His anger. Especially, the pre-exilic prophets give the threat of the wrath of God a central position in their preaching, the background of which is always the people's apostasy from YHWH and His covenantal instructions (משפטים).

If we look at the images and metaphors which the prophets in particular use in order to depict the divine wrath, it is clear that the divine wrath is different from human wrath and has an enormous effect. The image of wrath as a consuming fire is well known. When the wrath of YHWH is inflamed it can be said that a fire is burning in His nose (e.g. Je. I5:14; 1 7:4) and that smoke rises from it (Ps. 18:8). The tongue of YHWH is said to be a devouring fire in Isaiah 30:27. Apart from the metaphors of the divine wrath as glow, fire and violent storm, we read about a pouring out and a drinking of the wrath of God. YHWH pours out His wrath over His chosen people and over other nations as a man pours out water (e.g. Ho. 5:10). He can give people His wrath to drink (Jb. $2 \mathrm{I}: 20$ ) and let them drain the cup of wrath (Is. 5 I:1 7, 22 ; Je. $25: 15 ;$ Ps. 75:8). The image of the wine-press is used once (Is. 63:I-6). The divine wrath can manifest itself in a rain of fire and sulphur 
(Ezk. 38:22) or in streams of pitch (cf. Is. 30:33; 34:9). All these images underline the word in Psalm 76:7: 'Who may stand in thy sight when once thou art angry?'

But the wrath of YHWH is not only limited to the covenant people. It also includes the foreign nations and their rulers. In this case, too, the divine wrath is pictured as legitimate and righteous. The reasons can be several. When Israel is attacked, YHWH is attacked. The glory of His people is His own glory ( $c f$. Is. 48:9-I I). YHWH also has claims to dominion over the whole earth (Ps. 24:I). Therefore He reacts against the hubris of other peoples as well (Is. I0:5ff.; I3:I I i 6:6, etc.). His hand is stretched out upon all the nations (Is. I4:26). It is also presupposed that other peoples could and should have a certain knowledge of 'fear of God' (Gn. 20:I I) and a certain degree of moral insight (Am. $\mathrm{I}: 3-2: 3 ; \mathrm{Gn}$. 18:20ff.). Other nations are not allowed to do whatever they want just because they do not belong to the chosen people. In Genesis 15:16 we read about 'the iniquity of the Amorites' and that their iniquity during Abram's time 'is not yet full', and according to Genesis 19 Sodom and Gomorrah were overtaken by the wrath of God because of their inhabitants' immoral life, etc. Thus everybody is supposed to have some kind of religious and moral knowledge, and therefore the divine wrath is not depicted as a blind and uncontrolled outburst of disgust.

Several texts also stress that the wrath of YHWH can be turned aside. Because of His mercy and patience YHWH can let $\mathrm{His}$ wrath operate gently ( $c f . \mathrm{Ex} .34: 6$ f.; Nu. I4:18; Na. I:3) or hold it back totally ( $c f$. especially Ho. I I:9). When YHWH shows Israel His patience, He wants to give it an opportunity for conversion. The same is the case when YHWH shows His patience to Nineveh against the will of Jonah (4:2). YHWH can also wait to perform His punishment for other people's sins when He wants to punish or try His own people or to let the nation's sinfulness be still more obvious. He also wants to give room for conversion by postponing His punishment or by issuing a warning of it through His prophets. In Ezekiel I8:23 it is said that YHWH does not like to see the death of the ungodly, but on the contrary that He wants them to be converted to Him and be saved. The divine wrath, therefore, has also an educating function. But if the people still do not turn to YHWH 
(see Am. 4:6-12), the judgment must come in full scale (see Am. 9:8, Io; Is. 6:9ff.; Je. I 5:5-9). Yet the prophetic announcement of the inescapable doom often includes a begging cry for penitence and conversion, see e.g. Jeremiah r 8:7ff. and Jonah's preaching in Nineveh. The suppliant can turn to God's mercy and say: 'Have mercy upon me, $\mathrm{O}$ God, according to thy loving-kindness; according to the multitude of thy tender mercies blot out my transgressions' (Ps. 5I:I). Also a person's intercession can appeal to God's mercy. Thus Moses intercedes for the apostate people (Ex. 32:I Iff.; Nu. II:If.; I4:I Iff.; Dt. 9:19; Ps. 106:23) or for individuals (Nu. 12:13; Dt. 9:20). Such an intercession is heard by YHWH so that He turns away His wrath or diminishes its effect. But there may be a day when YHWH does not listen to any intercessions (Am. 7:8; 8:2; Ezk. 14:14), and even forbids His prophet to intercede for the apostates (Je. 7:16). Then the divine wrath will come upon the sinners in full scale (Ezk. 8:18). The proclamation of that day, when YHWH will intervene just as $\mathrm{He}$ is, is well anchored in the prophetic texts. That day will be a day of wrath for all who stand as His enemies and a day of redemption for all His friends.

\section{GONCLUSION}

The wrath of YHWH seems to have a natural place in the prophetic conception of God and to be a consequence of His holiness and righteousness. It is only when we take as our starting-point the evaluation of human wrath as imperfect and opposite to a good nature that the nature of YHWH seems to consist of incompatible traits. Here, I think, is the kernel of the problem. For it is one thing if it seems impossible to us to combine wrath with a perfect nature and another thing if the Old Testament texts also find such a combination impossible. If the context is allowed to determine the contents of the expression 'the wrath of YHWH', we do not get the impression of any incompatibility between the God of wrath and the God of love. Anger seems to be an essential element of YHWH's love which is inseparably connected with His holiness and His justice. Therefore He must manifest anger when confronted with sin and evil, even if some texts state how much YHWH loves His 
chosen people and therefore tries to hold back His wrath (see especially Ho. I I). Instead of being something problematic and negative in God's nature, the divine wrath is usually represented as a natural expression of His holiness and righteousness which must be maintained under all circumstances and at all costs. It is typical that Nahum $r: 6,7$ puts forward the question 'Who can stand before YHWH's indignation?' and at the same time says that 'YHWH is good'. The day of vengeance and the year of redemption or grace are presented as two aspects of the same thing. The one aims at those who remain in opposition to the saving God, the other refers to those who subordinate themselves to His rules and take their refuge in His grace. The proclamation of 'the acceptable year' in Isaiah $6 r: 2$ is the same as the proclamation of 'the day of vengeance' and that day will give comfort to 'all that mourn'. In the same way 'the day of vengeance' in Isaiah 63:4 is also called 'the year of my redeemed'. The picture of YHWH in this chapter as trampling the winepress easily gives us a negative and crude image of YHWH as a savage and bloodthirsty God. But I am convinced that the author intends to give a positive picture of $\mathrm{YHWH}$ with this chapter. He makes God say both 'I that speak in righteousness, mighty to save' (verse I) and 'I will tread down the people in mine anger' (verse 6).

Perhaps the picture the Old Testament texts themselves give can be justly summarized in these words: the wrath of $\mathrm{YHWH}$ is a personal quality, without which $\mathrm{YHWH}$ would cease to be fully righteous and His love would degenerate into sentimentality. 